\title{
A Radical Vision of Radicalism: Political Cynicism, not Incrementally Stronger Partisan Positions, Explains Political Radicalization
}

\author{
Alain Van Hiel \\ Ghent University \\ Jasper Van Assche \\ Ghent University \\ Tessa Haesevoets \\ Ghent University \\ David De Cremer \\ National University of Singapore
}

Gordon Hodson

Brock University

\begin{abstract}
Is political radicalization a product of increased issue position polarization, by which left and right-wing attitudes become ever more extreme? We argue that this is not the best explanation. Indeed, radical left and right supporters are not so much "left" or "right" in terms of their ideological attitudes. Instead, we argue that political cynicism is a relevant ideological attitude, with radicals being characterized by distinctly high levels, making them truly distinct from moderates. Radicals are primarily driven by anger, more than by anxiety, meaning that their information processing is heavily focused on consistency and closure. We discuss that political cynics have become highly effective as a political force, and we offer suggestions for how traditional parties may overcome the "trust crisis" in politics. It is concluded that issue-position polarization is a phenomenon that operates to an equal extent in moderate voters than in adherents of radical and populist parties. The abyss between moderates and radicals concerns whether or not "to be in the political system" at all.
\end{abstract}

KEY WORDS: anger, antiestablishment, political cynicism, political extremism, radicalism, trust crisis

This was my first proper insight into the eternal type of professional revolutionary who feels himself lifted out of his insignificance by the mere fact of being in opposition and who clings to his dogma because of a lack of resources within himself... The truth is that not one of those 
... was able to formulate a policy when the need was present ... [being] stuck in their carping, nagging negativism.

—Stefan Zweig (1943, p. 195)

Specific social or political ideas, which may be very "extreme" in one geographical or cultural context, may be very "moderate" in another context. For example, belief in the political and social equality of Blacks would most certainly have been a very "extreme" idea in the America of 1776 and is now becoming a very moderate idea.

—James Sidanius (1985, p. 639)

Two trends coappear in current society. A first trend is the raise of support for radical-populist parties, politicians, and ideas (Fagerholm, 2018; Whiteley et al., 2021). A second trend is the increasing degree of ideological polarization in terms of more extreme issue positions (Abramowitz $\&$ Saunders, 2008; Inglehart \& Norris, 2016; Simas et al., 2020). These trends, if continued, would culminate into a situation where the adherents of the left-wing and right-wing blocs become ever more extreme and therefore will have nothing in common anymore, or at least, that people perceive this to be the case (see Mason, 2015; Westfall et al., 2015). At first sight, both phenomena seem to go hand in hand. On the surface, polarization appears to be an important precursor of populism and radicalism, and it is almost self-evident that in times of polarization, radicalism is on the rise. Yet such apparent connections might not be on solid footing. In this contribution, we challenge the priority afforded to the idea that moderate people espouse ever more radical ideas because of issue position polarizationn (Isenberg, 1986), whereby more moderate left-wing adherents gradually become more and more attracted to radical left-wing parties and moderate right-wing supporters become ever more attracted to radical right-wing parties.

We first focus on issue position polarization, a phenomenon that has been introduced in classical group-dynamics literature. Issue position polarization is the psychological process that makes like-minded people become more extreme, and because of this, also more similar (Isenberg, 1986; Moscovici \& Zavalloni, 1969; Myers, 1982; Myers \& Lamm, 1976). Attempts have already been made to explicitly link issue position polarization to support for radical parties (see Harton \& Latané, 1997; Latané \& Nowak, 1994; Liu \& Latané, 1998). In contrast, we argue that, unlike the work of Latané and colleagues, and claims in the recent literature (e.g., Mouffe, 2005; Mudde \& Rovira Kaltwasser, 2018), issue position polarization (or the lack thereof in traditional parties) is not the best way to understand the rise in electoral support for radical parties. Rather, there is decisive evidence that issue position polarization is not the major driving force behind "political polarization," with other mechanisms likely at play, namely those rooted in political cynicism (Agger et al., 1961; Eisinger, 2000; Pattyn et al., 2012). From this perspective, the abyss between moderates and radicals concerns whether or not "to be in the political system" at all. Political cynicism, which entails a profoundly negative attitude towards and lack of trust in the establishment, is a most relevant political attitude which divides moderates from radicals and populists. The "classic" left-right ideological attitudes that are so familiar to us-like authoritarianism (Adorno et al., 1950) and social dominance orientation (Pratto et al., 1994) - mainly have relevance for moderates (also see Van Assche et al., 2019). If issue position polarization plays a role, then it is foremost important among moderates not radicals.

We also discuss the role of anxiety (Onraet et al., 2013, 2014) and anger (see Vasilopoulos et al., 2018, 2019a) in fueling radicalism, showing that anger holds more promise as an explanatory variable of political-cynicism-based radicalism and populism, and that anger provokes biased information search of politically relevant information. We end this contribution with the implications of political cynicism for democracy and discuss how traditional political parties can regain trust. 
Unlike the U.S. political situation, which is dominated by two political parties, the Western European political systems are often more complex and usually include many parties that can be arranged from moderate to radical, both at the left-wing and the right-wing sides (Huddy et al., 2018). Hence, in Europe changes in political attitudes may coincide with changes in politicalparty preferences, which makes radical- and populist-party support and its psychological backup easier to study. The present contribution is thus based largely on research conducted in European countries. That said, the rise of political cynicism at the expense of centrist ideas, the increasing popularity of populist and radical politicians, and the cleavage between the "ordinary people" and the establishment, is by no means solely a European affair, and our theory development has relevance for the U.S. political context as well (Oliver \& Rahn, 2018). Recent political events, and in particular the advent of Donald Trump, have demonstrated that partisans and elected officials may become receptive to a radical party leader's point of view, as was the case with Trump's hard-edge "America first" principle and gut-level cultural appeals (Bartels, 2018). This suggests that, in the United States, traditional parties are at risk of being taken over by populists and radicals (Bartels, 2020) and thus shows the dramatic effects that populism and radicalism may have on the American political system. Also note that in the present contribution, we use the terms radicalism and populism interchangeably, as both terms usually refer to the same political parties, which are mostly extreme on either the left-wing or the right-wing side of the political spectrum. ${ }^{1}$ Finally, in line with Mudde (2004), we reserved the term extreme for populist parties and movements that explicitly promote violence, and the term radical for populist parties that seek political change trough nonviolent means.

\section{How Does Issue Position Polarization Operate?}

It is well established that people infect each other with their opinions and attitudes, making themselves more extreme. Issue position polarization is the exaggeration of the initial individual tendencies through group discussion (Moscovici \& Zavalloni, 1969; Myers, 1982; Myers \& Lamm, 1976), with two traditional theoretical frameworks explaining such polarization (Isenberg, 1986). According to persuasive arguments theory, the attitudes of group members become more extreme as more convincing arguments become available and salient (Vinokur \& Burnstein, 1974). During group discussion, members are confronted with convincing arguments for a particular decision option - some new, others as a repetition of what they already thought—so that preexisting attitudes become more extreme (Brauer et al., 1995). This represents informational influence. The second explanation is based on social comparison and the desire to be liked. According to this approach, group polarization is explained by the exchange of views. Individuals discover like-minded others' points of view during group discussion, with the initial majority prevailing through normative pressure (Brown, 1965; Sanders \& Baron, 1977).

Attempts to apply the concept of issue polarization to political topics are understandable. There is no reason to assume that political attitudes necessarily develop differently than any other attitude type. Moreover, people form social groups with which they identify and in which they allow other group members to influence them (Abrams et al., 1990). They also prefer to associate with people from their own group (Allport, 1954). The rise of social media fits in nicely with the theories of issue position polarization: People interact with others who have similar opinions in their self-created echo chambers, resulting in people becoming increasingly convinced of their (own) cherished ideas (Grover et al., 2018; Iyengar \& Westwood, 2015).

An issue position polarization model has already been introduced and applied to political polarization: the catastrophe model of political attitudes (Harton \& Latané, 1997; Latané \& Nowak,

\footnotetext{
${ }^{1}$ Although relatively rare, various authors (e.g., Muller, 2016) have noted that centric populism is a possibility, and a common example in this respect is Silvio Berlusconi, a populist who was center right but not radical right wing.
} 
1994; Liu \& Latané, 1998). This model predicts that increasingly more extreme attitudes occur in political groups, even to the point that the worldview of members of such groups no longer corresponds to the perception of the general public. In the spirit in which this model is formulated, people drift further and further away from the middle in small steps, such that the eventually large quantitative differences ultimately become a qualitative difference. In terms of the left-right attitudinal dimension, this would imply a particular distribution of attitudes, with a flat distribution of attitudes of moderate people in the broad center, and narrow, steep distributions of attitudes in extreme circles, on the poles of the left-right continuum. The tails of the curves would hardly overlap, if at all.

Interestingly, the catastrophe model specifically includes an additional source of political polarization, namely the tendency of extremists to push themselves away from mainstream sentiment. Extremist movements create a dichotomy between themselves and their ideological opponents to mobilize support among members and neutralize possible external influence (Gamson, 1975; Simons $\&$ Mechling, 1981). This creates a fault line, with on the one hand one's own group (that is superior), and on the other hand the other groups (that are ill informed and misled). This process bears some similarities to that of negative partisanship, as members of other political groups are perceived most negatively (Iyengar \& Westwood, 2015; Mason, 2015). However, there exists a crucial difference: Political radicals tend to also hate the political system and establishment as a whole, with some even desiring to reverse or undo it.

Overall, the catastrophe model portrays extremism as a step-by-step evolution towards a separate consensus that deviates from mainstream thought. Yet one aspect, the step-by-step polarization into a separate consensus, is not well supported by the available data (as we outline below). In contrast, the aspect concerning antagonism toward the establishment is better supported and indeed fuels political radicalization and populism.

\section{Issue Position Polarization Does not Offer the Best Explanation of the Success of Political Radical Parties}

There are good reasons to suspect that support for political radical parties is unlikely the result of a step-by-step process linked to ideological left/right attitudes. Indeed, we first present existing empirical findings which allow us to conclude that the issue position polarization hypothesis is on weak footing. We then further analyze data of two samples reported in Van Assche et al. (2019) to directly show that right-wing attitudes are not particularly adequate to distinguish supporters of moderate right-wing from extreme right-wing adherents.

\section{Indirect Evidence}

A first empirical anomaly with regard to the issue polarization hypothesis is based on the tenet that such polarization should not only lead to more extreme attitudes but also to more similar attitudes within the group. Indeed, polarization is a process whereby group members tend to "think alike." ${ }^{2}$ However, this outcome is not empirically borne out for extremists. Van Hiel (2012) found that, especially on the extreme sides of the political spectrum (as opposed to the center), there is a wide variation in personal values such as openness, conformity, and safety, precisely those values that strongly correlate with left-right attitudes in moderate samples. It is striking that this greater heterogeneity occurred both on the radical-left side (perhaps not unexpectedly, because the radical

\footnotetext{
${ }^{2}$ Although some radical groups are not particularly well informed (e.g., QAnon), in general radicals are better informed than moderates about political issues, which increases the chance that people will be confronted with information that affirms their attitudes. They also often discuss politics with others (Van Hiel \& Mervielde, 2003), which creates situations in which issue position polarization can play its full role.
} 
left is notoriously famous for its lack of consensus) and on the right-wing side (perhaps less anticipated, because often there is more consensus here).

A second finding that works against the issue position polarization hypothesis is based on observations of political scientists. Mudde (2004) argued that populist parties are "ideologically poor"-unlike traditional left and right parties, they show less ideological coherence. Instead, they select left and right recipes that they embed in their own story as they see fit. The Italian Five-Star movement, for example, combines both typical left and right ingredients into a "new" soup bowl, and thus it cannot be called left or right, a dichotomy which party officials consider to be outdated (Mosca \& Tronconi, 2019). Consider also how, during the last elections of the Belgian parliament, the radical right-wing Vlaams Belang positioned itself on the left for socioeconomic themes. Likewise, the radical right-wing PVV in the Netherlands has also been in favor of policies that can be called progressive, especially in the domain of social measures. If radical right-wing voters would be hyperpolarized in terms of right-wing attitudes, such strategic repositioning of radical parties could have led to a loss of electoral support, or to opposition among party officials or supporters, but all of this did not happen.

\section{Direct Evidence: Reanalysis of Data of Van Assche et al. (2019)}

A final finding that runs contrary to the hypothesis of issue position polarization is related to the distinctiveness of radical political parties vis-à-vis other political parties. On the basis of party preferences, it is possible to segment the political landscape. In the Western European situation, for example, people who are positive about the program of the Social Democrats often have a positive orientation toward Green Parties as well, but not toward right-wing parties. In Belgian (Flemish) and Dutch samples, four distinct party types typically emerge: libertarian, traditional left, traditional right, and radical right. ${ }^{3}$ These right-wing radical parties (Flemish Block and Party for Freedom, respectively) are characterized by their anti-immigration platform, their focus on security, their political exploitation of corruption and other scandals, and their defense of traditional values (see Billiet \& De Witte, 1995). A relevant question in this context is whether the distinct preference for the radical right would be characterized by a very high score on right-wing ideological views among its adherents? The data suggest that it does not.

The research by Van Assche et al. (2019) sheds more light on the relative impact of right-wing attitudes. Two samples were included. A first sample of Flemish citizens $(N=509)$ without a migration background was collected by undergraduate students. These students recruited adults within their social network in order to obtain a heterogeneous community sample. The second sample was a nationally stratified sample of Dutch citizens $(N=628)$ without a migration background, collected through an independent survey company. In these two samples, the left-right attitudes were operationalized in terms of right-wing authoritarianism (RWA, Altemeyer, 1981) and social dominance orientation (SDO, Pratto et al., 1994). Two additional attitudinal scales were also administered: The political-cynicism scale developed by Pattyn and colleagues (2012) and the subtle racism scale (Pettigrew \& Meertens, 1995; Van Hiel \& Mervielde, 2005).

Van Assche et al. (2019) reported that, as reasonably can be expected, right-wing attitudes were related to radical right-wing party support and voting, but also that additional variance was consistently explained by political cynicism and ethnic prejudice. To further clarify these results, here we present a reanalysis of their data. Specifically, we created "purified" indicators of each construct by calculating $z$-standardized residual scores for each target variable (corrected for the other attitudinal scales in a regression analysis). As shown by Figure 1, (purified) right-wing attitudes are not particularly distinctive in characterizing radical-right supporters from the other ideological groups. Indeed, adherents of traditional right-wing parties obtained an even higher authoritarianism score than the radical-right supporters (a result reminiscent of the findings of

${ }^{3}$ The party landscape in these contexts lacks a radical-left party. 

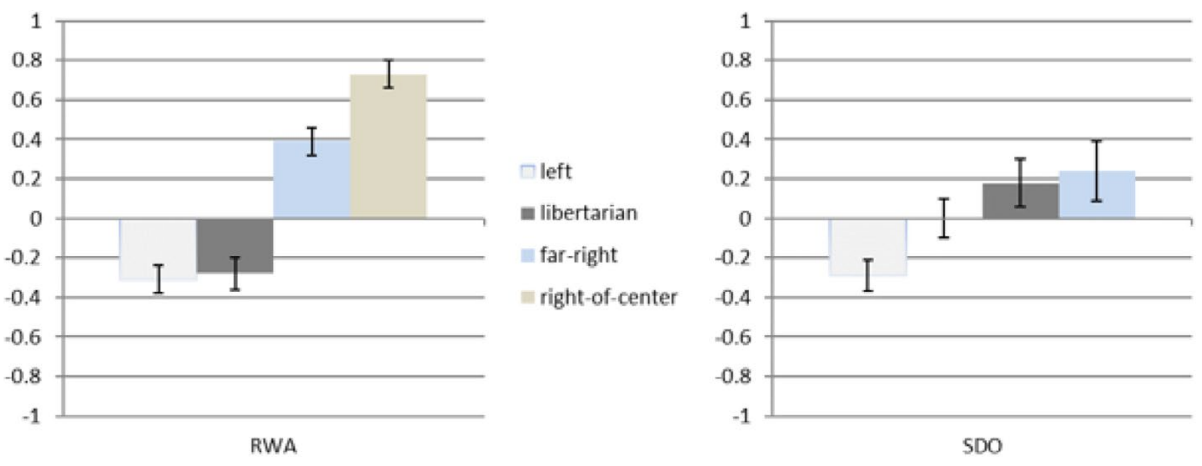

$\square$ left

is right-of-center

- libertarian

war-right

wight-of-center

SDO

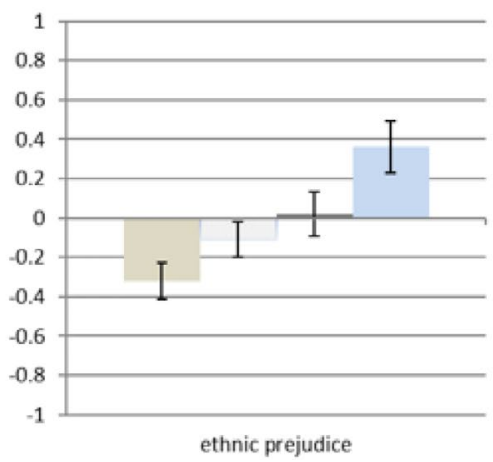

- libertarian

war-right

right-of-center $\square$ left

- libertarian

= far-right war-right wight-of-center

= libertarian

$\square$ left

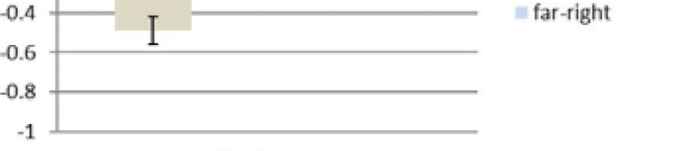

political cynicism

Figure 1. Standardized residual scores (with $95 \%$ confidence interval error bars) for RWA, SDO, political cynicism, and ethnic prejudice among left $(N=135)$, libertarian $(N=85)$, right-of-center $(N=98)$, and radical right-wing $(N=68)$ voters in the Netherlands (in ascending order per political alignment). These plots are based on a reanalysis of data reported in Van Assche et al. (2019). RWA, right-wing authoritarianism; SDO, social dominance orientation.

Van Hiel \& Mervielde, 2002); in terms of SDO, the libertarians and radicals showed quite similar scores. From this result it can be inferred that polarization in terms of expanding left and right attitudes becoming ever extreme is at least as characteristic for moderates as for radicals. What is particularly distinctive in characterizing the radical-right group, however, are political cynicism and ethnic prejudice. In fact, the radical-right group is the only group with substantial positive $z$-values in this respect.

In conclusion, left-right attitudes were less important in characterizing the radical-right position, but instead was particularly relevant to distinguish among the adherents of the various moderate parties. Put another way, the moderate and radical right do not differ much from each other in terms of being ideologically right wing. Instead, and this is the more important finding, political cynicism and antimigration attitudes are typical for supporters of radical right-wing parties.

\section{Conclusion}

In sum, based on these findings it is fair to conclude that polarization in terms of ever-increasing attitudinal left-right attitudinal differences is an unlikely candidate to form the basis of radicalism. Although we agree with Latané and colleagues that radicals substantially differ from moderates, it is clear that processes other than issue position polarization should be considered and might take priority. 


\section{Populism Captures the Ideology of Radical Parties, But it is not an Ideological Attitude}

What is it then that distinguished radicals from moderates? An important contemporary approach to define the individual's radical position—both at the left and the right—makes use of the concepts of radicalism and populism (Akkerman et al., 2014). According to Canovan (1999), "Populists in established democracies claim to speak for the silent majority of 'ordinary decent people,' whose interests and opinions are (they claim) regularly overridden by arrogant elites, corrupt politicians, and strident minorities" (p. 5). In the history of political psychology, there have been various attempts to demonstrate similarities on both radical sides of the political spectrum, which would distinguish them from moderates. These so-called extremism theories (see Eysenck, 1954; Rokeach, 1960) were not very successful and were often not supported by the data (see Brown, 1965).

In the interim, however, the political landscape has changed considerably, reopening this possibility. Indeed, recently, evidence on the similarity of radical-left and radical-right supporters has been presented. For instance, Zmigrod et al. (2020) collected a sample of American citizens and observed that partisan intensity goes together with reduced cognitive flexibility, irrespective of whether one's favorite party is left wing or right wing. In samples of American citizens, Lammers et al. (2017) showed that people on both ends of the political spectrum-strong Republicans and strong Democrats - form simpler and more clustered categories of political and nonpolitical stimuli than moderates. Also, in a large sample of Dutch voters, van Prooijen et al. (2015) reported that those at both ends of the political spectrum $(1=$ very left-wing $)$ and $(10=$ very right-wing $)$ are less tolerant of a number of societal groups (e.g., Bankers, Muslims) than those at the center. As all of these recent findings exemplify, adherents of radical parties at both sides resemble each other and at the same time are different from moderates.

The question arising here is whether we can identify a political attitude that is similarly shared by radical people and which differentiates them from moderates. We will explain that although populism describes the political party pamphlet of radical parties very well, it is not an ideological attitude in itself. Instead, we argue that political cynicism holds promise as being a relevant political attitude which makes people receptive of populist parties.

\section{Theoretical Considerations}

According to the rationale advanced by Mudde and colleagues (Akkerman et al., 2014; Mudde, 2004, 2007; Mudde \& Rovira Kaltwasser, 2018), there is a supply-and-demand side to populism (which we also apply to radicalism). The supply side is represented by the populist parties, whereas the demand side is represented by the populist electorate. The bottom line is that populist parties "serve" populist people by providing them with a direct political translation of their beliefs. Hence, a high level of congruence is assumed between the worldview of the radical person and the political pamphlet of radical parties. This perceived fit of ideas connects the party and its voters. Reasonable as it seems at first sight, this is a somewhat special vision within the domain of political psychology. We argue here that the populism concept is not the optimal way to describe the ideological attitudes of adherents of such parties, both for theoretical and empirical reasons.

Indeed, in the traditional study of ideological attitudes, the relationship between an ideology on the one hand and the attitudes of the individual on the other hand, is often less direct. The very concept of ideological attitudes assumes that this attitude is a basis that is not contained in ideology itself, but instead makes an individual receptive to a particular ideology (see Duckitt, 2001; Duckitt et al., 2002). For example, Adorno et al. (1950) considered authoritarianism as the individual's tendency to be receptive to the rhetoric and propaganda of fascist parties, and this without saying a word about this particular ideology (i.e., fascism) in the scale measuring the concept of authoritarianism. The pull towards radical parties is thus situated on a "deeper level"; it does not start from 
the phenomenon on the surface-namely the ideology itself. It is therefore "psychologized" and thus bears a less straightforward relationship with ideology. Hence, although we agree that supply and demand play a role, we believe that this relationship is more complex than an almost one-to-one relationship.

\section{Empirical Considerations}

There is also a problem on the empirical level. Akkerman et al. (2014) introduced a scale measuring "the demand side" of radicalism, and more specifically their populism facet scale serves this purpose. This scale is the most widely used psychological measurement of the populism concept (Roccato et al., 2019). All eight items of this populism scale reflect a very negative attitude towards politics and politicians, with the perceived rottenness of politics present in every scale item. In only four of these items, the perverse politician is directly contrasted with the pure people. Remarkably, no scale item exclusively gauges the perceived purity of the common people. It is therefore no exaggeration to state that the backbone of this scale is the negative conception of traditional politics and politicians, which in the end is nothing but political cynicism. The scales measuring populism and political cynicism thus show substantial conceptual overlap.

A further analysis by Van Hauwaert et al. (2020) of the populism scale of Akkerman et al. (2014) points to the most discriminating item between populists and nonpopulists: "What people call 'compromise' in politics is really just selling out on one's principles." This item lacks any reference to common "pure" people, and it would not be out of place in a scale that measures (political) cynicism.

\section{Analysis of Populism and Political-Cynicism Scales}

To investigate the distinctiveness of the populism and political-cynicism concepts more directly, Van Hiel et al. (2021) performed a joint analysis of both scales. To empirically show that populism and political cynicism are essentially measuring the same mindset, they administered the populism items of Akkerman et al. (2014) together with the political-cynicism items of Pattyn et al. (2012) in a sample of 198 adults living in the United States. Both the populism and political-cynicism scales yielded an acceptable internal consistency, and the correlation between both scales was highly significant and very strong, $r=.69, p<.001$.

A principal component analysis of the populism and cynicism items was conducted, based on the premise that if two scales are truly distinctive, the joint analysis of these scales should yield clean, separate dimensions, each of them with high loading items that refer to one of the scales (for the rationale of such analyses, see Lemery et al., 2002, and Lengua et al., 1998). As can be seen in Table 1, the first component consisted of a mix of populism and cynicism items; six populism items and four political-cynicism items had their primary loadings on this component. The second component also consisted of a mix of populism and political-cynicism items: Two populism items and four cynicism items had their highest loading on this component. It can thus be concluded that the items of these two scales tend to mix up, which according to the rationale of Lemery and colleagues does not lend support for their distinctiveness.

The confirmatory factor analysis reported by Van Hiel et al. (2021) confirmed the results of the exploratory analyses. Two models were compared: Model 1 in which all items load on one dimension, and Model 2 with a clean factorial structure with the populism items loading on one dimension, whereas the political-cynicism items were forced to load on another dimension. The difference in statistical fit between these two models was not statistically significant. Given that the two-factor solution did not show superior fit, the more parsimonious one-factor model should be preferred, again indicating that these two scales probe into essentially the same content. 
Table 1. Pattern Matrix Coefficients Among Cynicism and Populism Items, Based on a Principal Component Analysis with Direct OBLIMIN Rotation $(N=198)$

\begin{tabular}{|c|c|c|}
\hline & I & II \\
\hline Cynicism_01 People are very frequently manipulated by politicians & .56 & .11 \\
\hline Cynicism_02 Politicians are only interested in getting and maintaining power & 60 & .32 \\
\hline Cynicism_03 Politicians pretend to care more about people than they really do & .73 & .15 \\
\hline Cynicism_04 Our political leaders are prepared to lie to us whenever it suits their purposes & .57 & .36 \\
\hline $\begin{array}{l}\text { Cynicism_05 If a politician sticks to his ideals and principles, he is unlikely to reach the top of his } \\
\text { profession }\end{array}$ & .16 & .46 \\
\hline Cynicism_06 No man can hope to stay honest once he enters politics & -.14 & .78 \\
\hline $\begin{array}{l}\text { Cynicism_07 Almost all politicians will sell out their ideals or break their promises if it will } \\
\text { increase their power }\end{array}$ & .27 & .72 \\
\hline Cynicism_08 All politicians are bad—some are just worse than others & -.05 & .75 \\
\hline Populism_01 Politicians need to follow the will of the people & .66 & -.16 \\
\hline Populism_02 The people, and not politicians, should make our most important policy decisions & .51 & .01 \\
\hline $\begin{array}{l}\text { Populism_03 The political differences between the elite and the people are larger than the } \\
\text { differences among the people }\end{array}$ & .51 & .00 \\
\hline Populism_04 I would rather be represented by a citizen than by a specialized politician & .62 & -.05 \\
\hline Populism_05 Elected officials talk too much and take too little action & 64 & .12 \\
\hline Populism_06 Politics is ultimately a struggle between good and evil & .03 & 68 \\
\hline $\begin{array}{l}\text { Populism_07 What people call "compromise" in politics is really just selling out on one's } \\
\text { principles }\end{array}$ & -.03 & .78 \\
\hline Populism_08 Interest groups have too much influence over political decisions & .64 & -.14 \\
\hline
\end{tabular}

Note: Primary factor loadings in bold.

It can thus be concluded that the items of the populism and political-cynicism scales did not load on distinct dimensions in a principal component analysis, and that the theoretically valid twodimensional model did not show a significantly better fit than a one-factor model. The two scales thus showed substantial empirical overlap. For the sake of clarity, we repeat here that compared to populism theory, we hypothesize - in line with the ideological attitudes approach - that there is a less stringent connection between political cynicism and support for radical parties. Specifically, the latter two concepts cannot be equated; political cynicism is assumed to underlie such preferences rather than to be the sheer reflection of the political pamphlet of radical parties.

\section{Political Cynicism: A Relevant Ideological Attitude Distinguishing Moderates from Radicals}

From the joint analysis reported above, it can be inferred that the "new" populism scale by Akkerman and colleagues (2014) has not demonstrated that it offers something new to the "old" political-cynicism concept. In order to advance the literature, a new concept must be distinctive vis-à-vis already-known variables (also see Wuttke et al., 2020). This does not seem the case here. The political-cynicism concept has the further advantage that it forms an applied manifestation of a "deeper" personality concept, namely (general) cynicism. This is useful for checking the personality base in the form of related individual traits and locating the construct in more comprehensive personality models such as the five-factor (Costa \& McCrae, 1992) or HEXACO models (Ashton \& Lee, 2007).

Critically, consideration of the concept of political cynicism allows us to better understand the radical electorate. The so-called humane orientation of "populists" towards ordinary folks and common people is something that deserves further attention. The data of Pattyn et al. (2012) are particularly telling in this respect. These authors reported that the correlation between political cynicism and general cynicism is positive and strong, $r=.49, p<.001$. The general cynicism scale consists of items such as "Most people are just out for themselves" and "People will tell lies to get ahead." These 
items, of course, do not go together with the seemingly gentle orientation towards ordinary people which has been assumed to be present in adherents of populist parties (see Akkerman et al., 2014; Canovan, 1999; Mudde, 2007). Hence, although populist and radical politicians refer to ordinary people (also see Oliver \& Rahn, 2018) in the most kind and gentle words, and they actively claim to represent these citizens in their communication, such kindness is not characteristic of their cynical adherents. In other words, while it cannot be denied that the care for the interest of common people is a vital ingredient of populist parties' communication and ideology, as rightfully observed in political science, at the same time it should be stressed that the "common people theme" is not central to the ideological attitudes of their adherents.

Finally, political cynicism has a long history in political science and political thinking. Machiavelli (1532) and Rousseau (1762; see Grant, 2008) argued that deception and hypocrisy are basic ingredients of political success. Further, the concept of political cynicism among voters has drawn scholarly interest in the 1960s as "the extent to which people hold politicians and politics in disrepute" (Agger et al., 1961, p. 477). Political distrust is a part of the cynicism syndrome, but at the same time the concepts should be distinguished. Pattyn et al. (2012) argued that political cynicism represents an antagonistic form of contempt, with anger and hostility as two of its core elements. It is this emotional aspect that distinguishes the concept from mere lack of political trust, which refers to the more neutral and passive lack of faith in the (performance of) politicians and the current regime (Eisinger, 2000). One could say that all cynics have no trust; but, the opposite way around, the idea that all distrustful people are cynical, does not hold. Hence, politically cynical people show low trust, and they generally have active, overt negative feelings towards and negative expectations about the intentions and actions of politicians. It is exactly because of the powerful negative emotions embedded in political cynicism that makes it particularly central in shaping political preferences.

\section{Other Alignments Dividing the Moderate and Radical Electorate}

Political cynicism is, however, not the whole story underpinning why individuals are attracted to radical and populist parties. That said, it should be stressed that it is the one political attitude that left-wing and right-wing radicals share. Although the left-right attitudinal dimension is no longer the dominant factor differentiating between moderates and radicals, other dimensions that relate directly to policy choices have become particularly topical today. These alignments involve negative attitudes about the ever-increasing diversity that characterizes most Western countries (Van Assche et al., 2018, 2019) and a negative attitude towards big finance and economic globalization.

In radical right-wing circles, there is a very negative opinion about immigration and the presence of different ethnic-cultural groups in society. This dimension seemingly took some time to crystallize into a dominant political topic. Indeed, right-wing ideological attitudes were invariably considered as the basis of prejudice. An abundance of evidence was gathered for this over the years, in many political contexts (Sibley \& Duckitt, 2008). The idea that prejudice itself can form a basis of right-wing radicalism-alongside right-wing ideological beliefs - was not perceived as an interesting research question, as it seemed too self-evident. However, although diversity has been a lingering issue for quite some time, it has become increasingly important in the current political debate and thus has become a topic in its own right (see Bartels, 2020). Attitudes towards diversity may thus show an increasingly looser connection with left-right attitudes than in the past, yet may become an important additional source of radicalization.

The research by Van Assche et al. (2019), which we discussed above as evidence against the idea of an ever-increasing expansion of left and right ideological attitudes to extremes, illustrates how these alignments in terms of cynicism and prejudice contribute to the rearrangement of the political 
Table 2. Simple Slope Effects of RWA on Support for Traditional Right Parties (Christian Democratic Appeal—CDA, and Christian Union-CU) and Radical Right Parties (Party for Freedom-PVV, and Proud of the Netherlands-TON) in the Netherlands as a Function of Neighborhood-Level Diversity $(N=628)$

\begin{tabular}{|c|c|c|c|c|}
\hline \multirow{4}{*}{$\begin{array}{l}\text { RWA Effect in } \\
\text { Neighborhoods... }\end{array}$} & \multicolumn{2}{|c|}{ Traditional Right Parties } & \multicolumn{2}{|c|}{ Radical Right Parties } \\
\hline & CDA & $\mathrm{CU}$ & PVV & TON \\
\hline & $b$ & $b$ & $b$ & $b$ \\
\hline & $\left(\mathrm{CI}_{95}\right)$ & $\left(\mathrm{CI}_{95}\right)$ & $\left(\mathrm{CI}_{95}\right)$ & $\left(\mathrm{CI}_{95}\right)$ \\
\hline Low in diversity & $\begin{array}{l}0.41 * \\
(0.05 ; 0.77)\end{array}$ & $\begin{array}{l}0.52 * * \\
(0.14 ; 0.90)\end{array}$ & $\begin{array}{l}0.76 * * * \\
(0.42 ; 1.11)\end{array}$ & $\begin{array}{l}0.53 * * \\
(0.15 ; 0.91)\end{array}$ \\
\hline Medium in diversity & $\begin{array}{l}0.29 * \\
(0.04 ; 0.55)\end{array}$ & $\begin{array}{l}0.39 * * * \\
(0.12 ; 0.65)\end{array}$ & $\begin{array}{l}1.15 * * * \\
(0.91 ; 1.39)\end{array}$ & $\begin{array}{l}0.67 * * * \\
(0.49 ; 1.02)\end{array}$ \\
\hline High in diversity & $\begin{array}{l}0.18 \\
(-0.18 ; 0.53)\end{array}$ & $\begin{array}{l}0.25 \\
(-0.12 ; 0.63)\end{array}$ & $\begin{array}{l}1.54 * * * \\
(1.20 ; 1.88)\end{array}$ & $\begin{array}{l}0.99 * * * \\
(0.61 ; 1.37)\end{array}$ \\
\hline
\end{tabular}

Note: Unstandardized estimates reported, with $95 \%$ confidence intervals in parentheses. Reanalysis of data reported in Van Assche et al. (2018).

$* p<.05, * * p<.01, * * * p<.001$.

field. Specifically, radical-right parties were found to be particularly appealing to voters who are both highly politically cynical and who are biased against minorities (and negatively inclined towards immigration as well), even when the shared variance with right-wing attitudes was taken into account.

A further demonstration that "there is more than right-wing attitudes" to explain radical-right party preference can be found in research on the role of diversity. Table 2 (based on Van Assche et al., 2018) shows that in homogenous, low-diversity neighborhoods, right-wing attitudes coincide with voting for both traditional and radical right-wing parties. In high-diversity neighborhoods, however, right-wing attitudes are only related to a vote for radical right-wing parties. Particularly in highly heterogeneous neighborhoods, people with right-wing ideological attitudes are more negative towards immigration (Fasel et al., 2013; Karreth et al., 2015; Sibley et al., 2013). In other words, the relationship of right-wing attitudes to radical right-wing party preference depends on the diversity of one's neighborhood.

Comparable studies are needed in a political context which includes radical-left parties. The radical left draws on a reservoir of people who are politically cynical and anticapitalist and perceive globalization, international banking, and unbridled capitalism as a major problem (see Van Hauwaert \& Van Kessel, 2018). Just as political cynicism and immigration attitudes on the right-wing side are distinctive between radicals and moderates, political cynicism and anticapitalism attitudes are expected to distinguish moderates from supporters of radical left-wing parties such as Podemos in Spain and Popular Unity in Greece.

\section{A New Ideological Attitudes Model of Radical Party Support}

Before going into depth in the psychology of political cynicism, we present our new model of radical party support. The basis of this model explicitly resides in the ideological attitudes approach, and we acknowledge that other approaches — such as the one based on cognitive styles-may also shed a light of radical party support. Here we thus delineate the contours of our new attitudinal model of radical party support and present its distinctiveness vis-à-vis the traditional polarization model. In the new model, political cynicism has a central place. This section thus summarizes and formalizes our theoretical contributions.

A first issue in need of clarification, however, pertains to the relationship between political cynicism and left-right ideological attitudes, which we assume to depend on the specific political context (as 


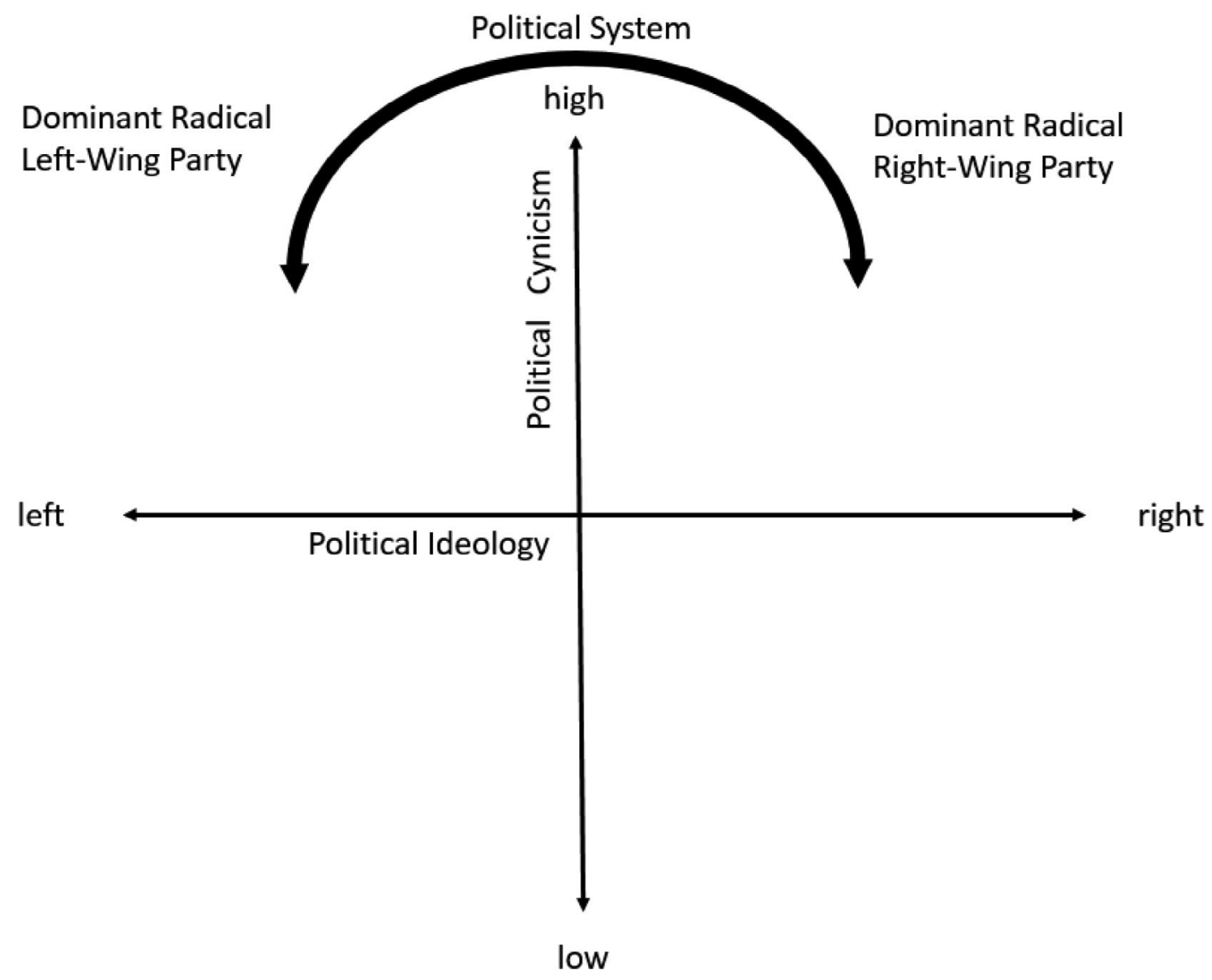

Figure 2. The relationship between left-right attitudes and political cynicism depends on the political context.

depicted in Figure 2). According to trait activation theory (Tett \& Burnett, 2003), activation of traits and their influence on behavior is contingent upon the availability of trait-relevant cues in the social context. Put differently, the theory proposes that a situation may "bring out" particular traits if a connection exists between the situation and the individual's trait (Judge \& Zapata, 2015). Interesting to the present research, Tett and Burnett (2003) noted that "a situation is relevant to a trait if it is thematically connected by the provision of cues ... [which] ... indicate a person's standing on the trait" (p. 502). Hence, the antiestablishment rhetoric of radical parties provides trait-relevant cues for political cynicism to be expressed in their adherents. If a political system only includes radical parties on the right-wing side of the political continuum, political cynicism will only flourish on that side, resulting in a positive correlation between right-wing attitudes and political cynicism. If the political system, however, includes both successful left-wing and right-wing radical parties, political cynicism will flourish at both sides of the continuum, resulting in a U-formed quadratic relationship, which reflects an orthogonal model.

Figures 3 and 4 present a graphical representation of the traditional polarization model and the new model we developed, to clarify their distinctiveness. Such a polarization model (see Figure 3) can be represented by a linear model: Increasing scores on right-wing (left-wing) ideological attitudes make people more and more susceptible for adherence to radical right-wing (or left-wing) parties. Hence, the step-by-step development of ever-increasing scores on right-wing (or left-wing) ideological scores paves the road for the electoral success of radical parties. A well-known example of such a linear model is authoritarianism theory (Adorno et al., 1950), although this theory only 


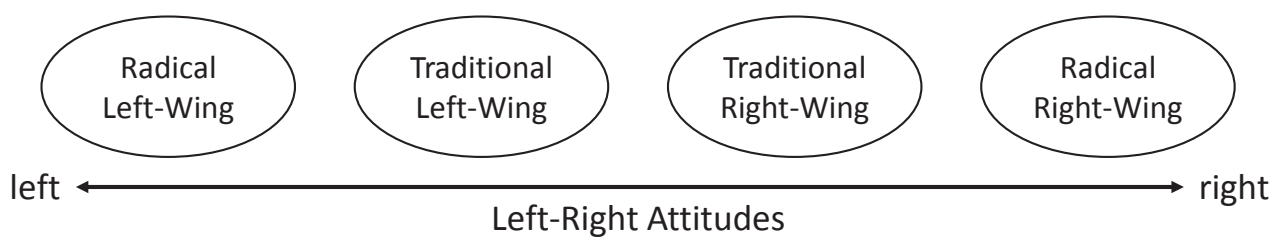

Anti-Globalization Attitudes

Pro-Globalization Attitudes

Pro-Migration Attitudes

Anti-Migration Attitudes

Figure 3. A graphical representation of the traditional polarization model of support for radical parties.
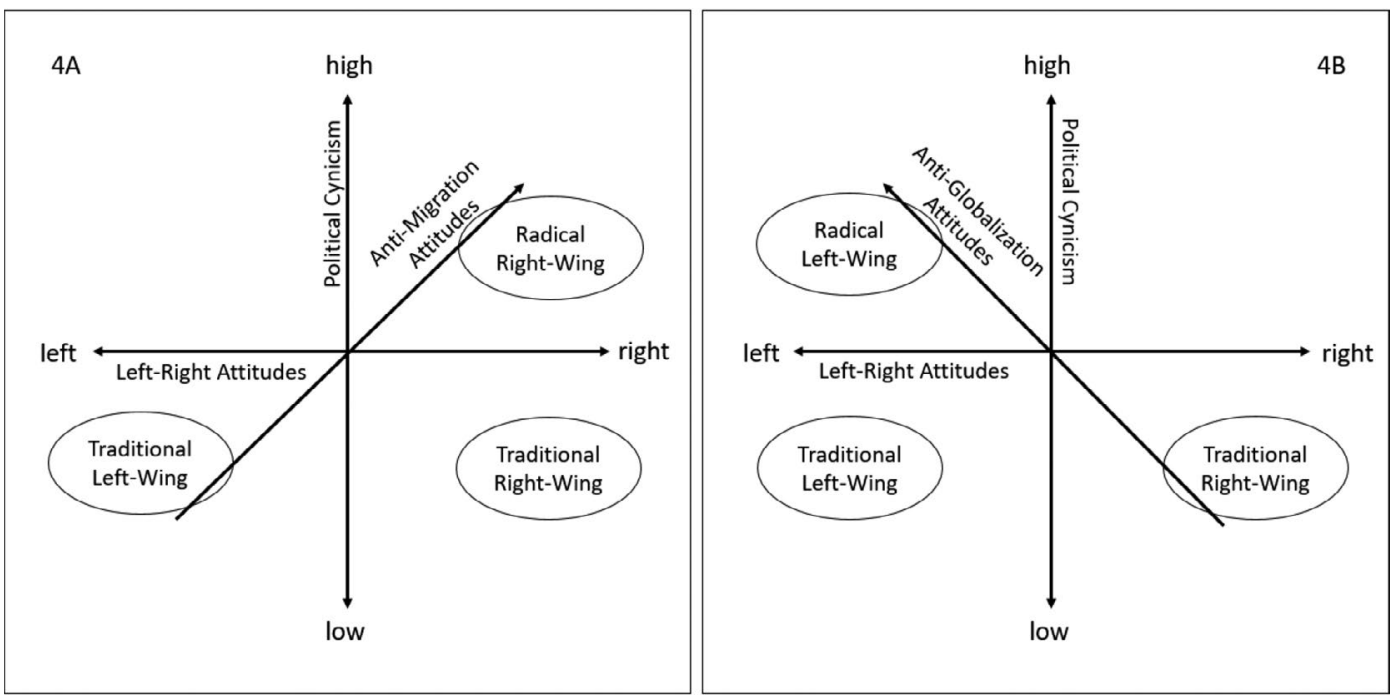

Figure 4. A graphical representation of the present model of support for radical parties.

focused on right-wing extremism. The more authoritarian an individual is, the more this person supports extremist parties. Also note that in the traditional model the migration and globalization attitudes are considered to coincide with left-right attitudes.

Conversely, as Figure 4 clarifies, our four-dimensional new model of radical party support deviates from the polarization model (Figure 3 ) in at least four ways: (1) it consists of the political-cynicism dimension (instead of populism) as "a new" (distinctive, but possibly correlating) ideological dimension with high scores among (left-wing and right-wing) radicals; (2) it limits the relevance of left/right ideological attitudes to moderate parties support; and (3) it includes the globalization and migration attitudes as relevant new dimensions and "topics in their own right," which relate to radical-left and radical-right party support, respectively. As we argue in the next section, the model also (4) stresses the role of anger in political cynicism (as opposed to the relevance of anxiety for right-wing attitudes).

\section{Towards a Psychology of Political Cynicism}

In this section, we pay attention to political cynicism in terms of psychological processes. Specifically, we argue that political cynicism and right-wing attitudes have a different emotional 
basis, and that cynicism is typically rooted in anger, leading to biased information search and processing. Next, we go into depth into the cynic's belief superiority and dogmatic intolerance against "other" opinions. Finally, we discuss the presumed political inefficacy of political cynics, as has been advanced in classic literature, and we argue that such inefficacy can be attributed to the political context rather than being an inherent characteristic of political cynicism itself.

\section{The Role of Anger and Anxiety}

Literature on right-wing attitudes claims that a portion of the electorate votes radically because of anxiety and threat proneness. Hundreds of studies primarily conducted in samples of moderates provided evidence for such a relationship, which is particularly present with societal threats (see Onraet et al., 2013, 2014). However, heavy focus on this particular emotion has distracted the research community from investigating other emotions that may play an even bigger role.

Indeed, recent studies indicate that radical attitudes are driven more by anger than by anxiety. ${ }^{4}$ Anger is accompanied by an increase in populism in situations, such as after the Charlie Hebdo attacks in Paris (Vasilopoulos et al., 2018, 2019a). Anger also plays a role in attitudes towards immigration (Hartley \& Pedersen, 2015; Verkuyten, 2004). The role of anger in radicalism is not just a radical-right phenomenon, but it is relevant also among radical leftists, as evidenced after the financial and housing-market crisis in Spain (Rico et al., 2017). During the 2008 financial crisis, people in the United Kingdom were angry with the government, especially if holding the government responsible for the situation, for example, due to financial-sector deregulation (Wagner, 2014). Another important source of anger resides in injustice perceptions. Indeed, a vast amount of research has shown that procedural justice violations particularly elicit anger-related emotions (De Cremer \& Van Hiel, 2010; Folger \& Cropanzano, 1998; Mikula et al., 1998), and perceived injustice has been related to radicalism and extremism as well (van den Bos, 2020).

The notion that anger plays a major role in the leap to radicalism is in line with the idea that political cynicism is important. Conceptually, political cynicism is not based on threat and anxiety, but it is rather an antagonistic form of contempt, with anger and hostility as two of its core elements (Eisinger, 2000). Precisely because of the powerful negative emotions embedded in political cynicism, it may be an ideal candidate for shaping radical party-political support (see Van Assche et al., 2018).

Anger indeed undermines confidence in politics and feeds antipathy towards politicians from other parties (Webster, 2018). Anger also leads to the biased search of information, whereby opinion-consistent information is especially favored (Suhay \& Erisen, 2018). Anger also exacerbates the tendency to accept as such incorrect information that favors one's own group (Weeks, 2015). On the Internet, anger-inducing information (such as in political advertising) yields higher click-through rates (Ryan, 2012) and is more easily distributed to others in one's social network (Hasell \& Weeks, 2016), all of which can lead to an echo-chamber dynamic (Wollebaek et al., 2019). This, of course, does not imply that people are exclusively subdued in a circle of likeminded people, but it cannot be denied that for most citizens their social network is dominated by people with similar opinions (Bakshy et al., 2015). In such ways, one's own attitude is increasingly being fed by new "evidence," which may lead to even greater antipathy towards political opponents and the political system. Anger is therefore an emotion that feeds political cynicism, which ensures that one's cynical attitude is increasingly confirmed. Anxiety, in contrast, does not show such effects; it instead urges caution and therefore often leads to the search for information inconsistent with one's beliefs (Wollebaek et al., 2019), presumably as a strategy that serves a person to be reassured ("It's not as bad as I initially thought").

\footnotetext{
${ }^{4}$ We acknowledge that other experiences that are affect-laden may lead to support for radical parties, such as the experience of being ostracized (Hales \& Williams, 2018).
} 
While we stress the role of anger and call for further investigation of this emotion in political psychology, we do not want to convey the message that anxiety does not matter at all. In an interesting study, Frimer et al. (2019) have shown that adherents of both radical left and right express more angry language (e.g., on social media, in U.S. congress, and so on), but these authors suggested that this anger was attributable to feelings of threat caused by political rivals. Along similar lines, Jost (2019) has suggested that threat may be an antecedent of anger. However, and this is the more important point, in each of these studies (Frimer et al., 2019; Jost, 2019; see Vasilopoulos et al., 2019a), anger is more strongly related to radical party preference than anxiety. Moreover, the simultaneous inclusion of both variables even reveals a negative direct effect of anxiety (Vasilopoulos et al., 2019b).

The fact that anger is more prevalent in radical people than in moderates is an additional piece of evidence that the political attitudes of moderates and radicals are truly distinct. If the relevant attitudes of each group had the same emotional basis, this finding would instead be in line with the idea that the moderate and radical positions are variations of each other, albeit with different intensity. Specifically, we argue that the observed difference in the emotional basis reveals that radicalism is not just an enlarged and polarized version of moderate ideology but rather represents "something else."

\section{Belief Superiority and Dogmatic Intolerance}

As we already discussed in the context of the catastrophe model, at least one part of this model holds promise as a rightful component of the political cynic's psychological functioning. Indeed, radical movements create a dichotomy between themselves and their ideological opponents not only to mobilize support among their members but also to neutralize possible external influence (Gamson, 1975; Simons \& Mechling, 1981). This creates a fault line, with on the one hand one's own group (that is said to be superior), and on the other hand the other groups (that are said to be ill informed and misled). A relevant question arising here is whether radical movements are successful in disseminating this perspective among their followers. A study conducted by Toner et al. (2013) speaks to this issue. These authors reported, in a sample collected in the general public, greater belief superiority at the more extreme positions (i.e., very liberal (1) and very conservative (5) on a 5-point politicalideology self-placement scale) compared to the moderate positions (i.e., 2 to 4 ). It is useful here to clarify the concept of belief superiority by comparing it with belief certainty. Belief certainty pertains to the degree to which people are sure about the views they hold; belief superiority, however, entails a social comparison and thus explicitly represents the idea that one's beliefs or attitudes are better than those of other people (Petty et al., 2007). One can be certain about one's ideas, but this does not imply that one thinks his or her ideas are better (or not) than those held by others. Certainty and superiority are therefore two distinct concepts.

Dogmatic intolerance is another interesting variable. In three studies conducted in the general public, van Prooijen and Krouwel (2017) measured dogmatic intolerance with items like "I believe that everyone should think like me"; "If everyone would think about it, they would hold the same opinions as I do"; and "How I feel about issues is the truth." Again, self-placement scales were used (e.g., ranging from $1=$ very left-wing to $10=$ very right-wing). These authors reported significant quadratic effects showing the highest scores on dogmatic intolerance at the low and high ends of the self-placement left/right scale. The concepts of belief superiority and dogmatic intolerance resonate well with the writings of Gamson (1975) and Simons and Mechling (1981). The suggestion here is that attempts of radical parties to elicit such superiority beliefs and dogmatic intolerance fit well with the mindset of their followers (and vice versa), and thus they might serve as a mechanism to mobilize support. Future studies may therefore directly investigate whether cynical people may show belief superiority and dogmatic intolerance and whether this contributes to populist party support. 


\section{Political Efficacy}

From the previous paragraphs, it can be concluded that political cynicism is a creature that continuously feeds itself, fueled by anger and by biased information-processing strategies. A relevant question is what do people $d o$ with this cynical attitude? Do they merely fight their small, personal wars on social media, or do they also try to make a true difference in the political arena, for instance when casting their vote in the ballot box or engaging in collective action such as political protest?

Most scientists would agree that high political cynicism is accompanied by a lack of perceived political efficacy (see De Vreese, 2005). According to this view, cynical people no longer believe that their political actions make any difference. They are averse to politics and, at the same time, do not take action because "the ship is already sunk anyway." There is a great deal of research on collective action that has been applied to the willingness to vote in elections, and a reduced level of perceived political efficacy is indeed linked to a lack of engagement (e.g., Valentino et al., 2011; Van Zomeren, 2016; Van Zomeren et al., 2016).

There are circumstances, however, which allow political cynics to suddenly become a major political force, and anger can play a role in this process (see Rico et al., 2020; Weber, 2013). One such situation is when elections have a high stake in terms of the overall political system. Van Zomeren et al. (2016) showed that anger indeed played a role during the Italian elections in 2013, where the radical Five-Star Movement and the right-wing populist Lega Nord became important political forces. Angry Italians with a deep antipathy towards the traditional politics and politicians suddenly had the opportunity to change the system with their vote, which represented an entirely novel situation for them. Meaningful here is that the anger about the overall political system (as characterized by cynicism) contributed positively to the intention to vote, while the anger towards the incumbent government (as comprised in negative partisanship) played no significant role.

Politically cynical people may (rightly) assume that their vote does indeed make a difference, as such raising their political efficacy. Supporters of the Five-Star Movement, for instance, "suddenly" witnessed that the polls predicted electoral success. In the past, politically cynical voters would have left the political system because they could only vote for small, marginal parties with little electoral weight, which were never allowed to participate in any government or decision body. Cynics were not able to change the political landscape and could solely communicate their discontent by casting a protest vote (e.g., a spoiled ballot, or voting for a candidate with no hope of winning). However, when radical parties have a realistic chance to become game changers in the political system, the cynic's vote makes a difference, activating segments of the voting public. This was the case in Italy where, at a certain moment, the radical parties gained the majority.

We are now living in times in which radical options are gaining momentum, being electorally successful, despite representing marginal options in a not-so-distant past. The situation has thus changed dramatically for the political cynic. As such, we assume that the lack of political efficacy presumed in the classic literature is at least in part situated in the political context, and not entirely in the psychological makeup of the politically cynic individual.

\section{Political Ramifications of Cynicism}

Are cynical people antidemocratic, representing a major threat to the current political system, or are they the messengers of political change that eventually will benefit democracy? Both potentials are valid. As noted by Pattyn et al. (2012): "Historically, the term cynicism stems from a Hellenistic philosophical school famous for criticizing ancient Greek society. By publicly ridiculing anyone who seemed pompous, materialistic or pretentious, they held up a mirror to society, hoping to elicit change therein" (p. 566). Moreover, according to De Vreese (2005), cynicism is positively related to political refinement, suggesting that cynicism is an indication of an "interested and critical citizen." 
Furthermore, this author stated: "It seems that citizens have the capacity to be both interested and knowledgeable about politics while at the same time critical and rather disparaging about politicians and their performance" (p. 294).

Nevertheless, most researchers have expressed negative ideas about (political) cynicism. Indeed, a recurring theme in literature is that political cynicism is harmful to political participation (see Patterson, 2002). Because democratic governments derive their authority from public support, a persistently high level of political cynicism threatens their credibility and legitimacy. But even if the legitimacy of the government is not at risk, a politically cynical climate has been shown to lead to a situation in which political leaders have a harder time solving societal problems (Chanley et al., 2000; Neustadt, 1990). As a result, they make weak decisions and fail to address controversial issues decisively (Hetherington, 1998; Porter, 2008).

In this section, we first argue that the political situation is suffering from a trust crisis (Hardin, 2006). Political distrust and cynicism are high, as manifested by the startling high figure of not less than three-quarters of the electorate which nowadays does not trust anymore politics and politicians. Next, we discuss how center parties - traditional parties and new movements - can react to the upraise of cynicism. Finally, building on the distinction between genuine and toxic radicalism, we discuss Trumpism as an example of the latter type of radicalism.

\section{The Political Trust Crisis}

On the back cover of The Cynical Americans - a seminal book written in 1989 by Donald Kanter and Philip Mirvis-it is stated: "Cynicism is growing rampant in America. It pervades the workplace. Worse yet, you, your boss, and fellow co-workers may be cynics and not even know it. This corrosive outlook threatens our personal lives, organizations, communities, and country." It seems as if in any period, people feel themselves to be living in cynical times. However, many people have lost their faith in traditional politics and politicians, and this seems truer now than before. What better way to demonstrate the inadequacy of the traditional parties than with figures about political distrust? In the broad literature, a common understanding has grown that "trust is a psychological state comprising the intention to accept vulnerability based upon positive expectations of the intentions or behavior of another" (Rousseau et al., 1998, p. 395). Trust has been considered a social glue connecting people and, as such, as an important and necessary precondition for cooperation to occur (De Cremer \& Tyler, 2005; Pruit \& Kimmel, 1977). Trust is not only important in interpersonal contexts, but societal institutions also need to be trusted in order to elicit cooperation (Jackson et al., 2012; Tyler, 1990). People assign power to politicians hoping that they will make good use of it, for the people's prosperity and well-being. Political actors must therefore ensure that they are not perceived as people who only serve their own interests and the interest of "not-the-people." The question arising here, therefore, is whether the establishment has succeeded in eliciting trust among citizens.

Numerous surveys and polls show how political trust keeps on eroding. It has widely been argued that we now live in an "age of distrust" (Da Silva, 2009, p. 86; also see Hardin, 2006). Citrin and Stoker (2018) have investigated trust in the American government over a period of six decades. These authors have shown that in the 1960s and 1970s there was a gradual decline in trust, which preceded a more volatile period until 2004, after which trust eroded down to an all-time low in 2016 (the last year of the survey). Recent surveys around the world indicate that trust in politics remains at a historical low. According to the Pew Research Center (2019a), the percentage of Americans who trust the government dropped from $73 \%$ in 1958 to below $30 \%$ in 2007 . Since 2007, the percentage of Americans trusting the government (pooled responses of always and most of the time) has not surpassed 30\%, although there seems a modest upturn since Joe Biden has been in office (i.e., April 10, 2021, the percentage was 24). Such trends of declining trust are not only observed in 
the United States, but also in many European, Asian, and African countries. For instance, the latest Edelman Trust Barometer (2021) — an annual online survey conducted in 27 countries with over 33,000 respondents-reported that in 2021 governments were distrusted in 13 surveyed countries. The IPSOS (2019) Global Trust in Professions poll $(N \approx 20,000)$ revealed that politicians and government officials are considered the least trustworthy professions. More specifically, in their 2019 poll, politicians were considered the most untrustworthy profession in all 23 surveyed countries-with $67 \%$ of the respondents agreeing that politicians cannot be trusted. This decline in trust is problematic, and as it is one of the constituting elements of political cynicism, it is not surprising that political cynicism is rampant. Many would, however, wish it were different. A recently published survey of the Pew Research Center (2019b) reported that the large majority of the general population wishes that trust in politics would rise and that more than $80 \%$ thought that such improvements are possible.

Given the low trust shown in many countries, the political enterprise is in need of change, but improvement of this situation is unlikely to occur soon. Taking into account that not less than threequarters of the citizens do not trust traditional politics and politicians, possibly wanting to electorally "punish" them (Hobolt \& Tilley, 2016), it should come as no surprise that antiestablishment candidates like Donald Trump and parties such as the Five Star Movement in Italy and Party for Freedom (PVV) in the Netherlands are able to attract a large number of voters. In fact, the $75 \%$ share of votes of distrustful citizens can be considered the possible upper limit of the voter potential of radicalpopulist parties. Of course, not everyone in this large reservoir is a supporter of radical-populist parties, and many of these people have "just" lost their interest in politics, or vote on moderate parties out of habit, without much reflection. It is highly doubtful, however, that when their political engagement is revived, it will be for the benefit of the traditional parties, which have elicited their indifference and disinterest in the first place.

\section{How to Overcome the Trust Crisis in Politics: Lessons for Moderate Parties}

What can reverse the trust crisis in politics, thus helping to reduce political cynicism? Bridging the trust divide between the general population and the government is certainly not an easy task. Political action against distrust and cynicism from a polarization lens is unlikely to succeed, and is probably even counterproductive. Indeed, a possible reaction is to try to take advantage of the fact that issue position polarization might still be a valid explanation for the ideological polarization of the moderate electorate (as opposed to the genesis of radicalism, which as we argued, is not well explained by issue position polarization). A possible reaction of traditional parties, therefore, might be to align themselves with their ideologically polarizing electorate, implying political polarization by which moderate left-wing parties would become more left-wing, and moderate right-wing parties more right wing. Shifts towards extreme positions have already been observed among moderate right-wing parties for immigration policies, particularly after the electoral successes of radical right-wing parties (Abou-Chadi, 2016; Carvalho, 2017). Such a strategy, however, is unlikely to be successful for at least two reasons. First, one problem is that traditional left and right parties depend on each other, especially in the context of multiparty systems (Haselmayer \& Jenny, 2018); in order to successfully implement policies, it is in their own interest to cooperate with one another, which requires good compromises with broad support. In terms of philosophy, good syntheses, so to speak, require the sound integration of theses and antitheses (e.g., Hegel, 1970/1807). Ideological polarization, however, further divides the traditional parties and may increase their powerlessness to cooperate and to come to solutions together, which prohibits the formulation of convincing answers on the fundamental issues raised by the radical parties. Second, another problem is that, all too often, there is a world of difference between the bold statements before the elections and the actual policies afterwards. This is, of course, especially the case for coalition governments in which parties work together and must willingly compromise, but even when a single party holds power, reality is often 
more unruly than expected. The difference between preelection rhetoric and postelection lack of action, in turn, further undermines trust and feeds political cynicism (see Pattyn et al., 2012), paving the road for further electoral success of radical parties.

It is important to realize that in times of great political distrust and rising political cynicism, the central political struggle is over the legitimacy of the system, which includes both the left-wing and right-wing traditional parties. The situation in which traditional parties find themselves is very much like a social dilemma. In a social-dilemma situation, people are torn between the desire to benefit themselves and the moral obligation to care for others and the collective (Kollock, 1998; Komorita $\&$ Parks, 1995). A soccer player may feel the need to score from a seemingly impossible angle, while a teammate stands alone in front of the goal. Likewise, we may want more than our share of scarce, valuable resources (such as water and clean air), while this leaves less or nothing for others. In both cases the individual gets the most benefit from pursuing self-interest. However, if everyone acts in such ways, football teams will no longer score goals, and our planet will be ruined. The same logic applies to the traditional political parties. If the traditional parties want to build a dam against radicalism, they will have to think in terms of the collective and focus on cooperation; this goal is not served by feeding the high degree of issue position polarization among its adherents, but instead policies that foster depolarization should be preferred.

Another strategy resides in portraying radical parties as populist, demagogic, and irresponsible and their adherents as indecent and marginal "deplorables" (Van Assche et al., 2019). It is, however, doubtful that the latter strategy will bring the radical voter back to the traditional herd, as shown by Stavrakakis and Katsambekis (2019) in the Greek political context. Another plan that is doomed to fail is to simply copy parts of the political pamphlet of radical parties, as this does not alleviate the deeper level problem of trust concerns. Such a focal strategy might even backlash and be experienced as too good to be true (Steinel et al., 2014).

More effective action from the traditional parties themselves should explicitly target trust issues. They will need to acknowledge that the concerns of radical voters should not be ignored. Oliver and Rahn (2018) refer to the situation in which political parties are not responding to the desires of large sections of the electorate as the "representation gap" (p. 194), which they consider an important antecedent of the raise of populist politicians. Traditional parties will thus have to take positions on immigration and globalization, and they will have to debate these new positions with the electorate. If they distance themselves from past decisions, they cannot but take responsibility for what went wrong at that time. In order to regain trust, it is an option to symbolize this distance with the past by apologizing for it (e.g., Scher \& Darley, 1997; Schmitt et al., 2004).

If the moderate, establishment parties do not succeed in joining forces against cynicism, the political counterreaction, of course, can also come from nontraditional parties that try to unite the political center. Western Europe is witnessing such antiradical initiatives. Consider the political movement of Emanuel Macron, La République en Marche (or, abbreviated, "en Marche"). En Marche explicitly distances itself from the opposition between left and right as well as from the traditional parties. In other words, this party tries to transcend the left-right contradictions, and this is particularly achieved by the movement's claim of technocratic competence. Moreover, the movement positions itself as an antiestablishment party (see Ivaldi, 2019; Perottino \& Guasti, 2020). This new movement thus united the political middle and at the same time marginalized the important political parties that had dominated France for decades (especially the Social Democrats and Republicans). En Marche became the challenger of the radical right (i.e., Marine Le Pen's Front National). The positive campaign of the Macron movement was striking and paid off electorally.

In conclusion, in order to respond to the electoral success of radical parties, moderate parties should not try to be too responsive to the attitudinal polarization of their adherents. The strategy of portraying radical and populist parties (and their followers) as irresponsible or to copy and paste 
parts of the political pamphlet of these parties will not work. Such strategies do not alleviate the underlying problem, that is, the lack of political trust. In order to bring citizens back into the political establishment, moderate parties should instead realize that the main political challenge resides in regaining legitimacy, which requires joint effort.

\section{Radical Parties and Political Change: For Better or Worse}

In many ways, radical parties are like "canaries in the coalmine," signaling that a part of the electorate believes that the political establishment is inadequate. Radical parties highlight the major problems and, like other parties, seek to gain voter approval. Some of these radical parties can be considered to be legitimate political forces. Indeed, repeatedly insisting on certain program points is not an attack on democracy, but, instead, it is an inherent feature of the democratic process itself (De Ceulaer, 2020). Moscovici (1976) already stressed that minority opinions are the motor of societal change (which he called "conversion") and that things would never change if majorities would always prevail. However, not all radical movements can be considered genuine, and some radical parties and movements surely pose a threat to democracy, especially in countries with weak political and social institutions (Weyland, 2020).

A discussion of political cynicism is incomplete without considering "toxic radicalism." Toxic radicalism does not envisage revealing the truth among its adherents but instead aims to feed frustration, general negativism, and revanchism with the sole aim of serving the personal interests of the leader (who is presented as the one and only alternative for a failing establishment). ${ }^{5}$ The presidency of Donald Trump is a recent example of toxic radicalism. Donald Trump tried to fill the minds of his cynical adherents with "alternative facts." Here facts have been replaced by appeals to emotion and subjectivity (McDermott, 2019), which in turn form the basis of a new consensual belief that replaces the original facts. In this context, it is relevant to make a distinction between misinformation and disinformation. Misinformation refers to the communication of inaccurate or false information without the explicit intention to mislead (Nyhan \& Reifler, 2010). Conversely, as Hameleers (2020) writes, disinformation refers to the intentional fabrication of (half) lies though the use of techniques such as manipulation and decontextualization. Trumpism, then, embodies the frequent use of disinformation.

Toxic radicalism is not only about telling lies. Even worse, the status of truth itself is compromised, and people are led to believe that the distinction between truth and falsity is not rooted in an objective reality, but instead in differing social conventions, and that there are many radically different and even incompatible ways, yet equally valid, of knowing the world (Dillet, 2017). Toxic radicalism thus does not clarify the contours of the truth but instead conceals them. Instead of making people virtuous, disinformation poisons the mind of countless citizens. It manipulates cynical people to the point of alienating them from reality (Bakir \& McStay, 2018; McDermott, 2019). Moreover, as we argued above, social media has the capacity to reinforce one's opinion: People read and hear more and more of the same information, come to believe this information more and more, and become more certain about it (see McDermott, 2019), up to a level that such views-even if shown to be wrong - can hardly be corrected (Morris et al., 2020). Toxic radicalism thrives on political cynicism but perverts it among its supporters, victimizing the truth itself.

Political cynicism lies at the basis of powerful processes. Disgust for the political establishment makes people receptive of critical messages about the policies and actions of political actors (De Vreese, 2005), but also to disinformation and grotesque manipulations of the truth. History has revealed to us that untruths are to be actively belied. One of the archetypes of toxic radicalism is the terror regime of Robespierre during the French Revolution. As has been shown by Jonathan Israel

${ }^{5}$ Bass and Steidlmeier (1999) expressed similar ideas for distinguishing between authentic and pseudo transformational leadership. 
(2014), at the basis of the rise of Robespierre lies the slanderous and misleading propaganda of JeanPaul Marat. The famous philosopher Karl Popper (1945) once presented the paradox of tolerance, namely that tolerant societies must be intolerant of one thing, namely intolerance itself. We would like to add that such societies, however, should primarily be intolerant of lies and grotesque falsehoods. Well-informed citizens themselves can be expected to be resistant to intolerance if they know the truth.

\section{Concluding Remarks}

As the quotes in the beginning of the present article exemplify, some authors have championed the positive side of political radicalism, as did James Sidanius. Many others, however, have warned of the dangers of radicalism. Stefan Zweig-the famous Austrian writer whose entire oeuvre was put on fire (together with other "un-German books") by the Nazis—-had an outright negative opinion about any form of radicalism. Some genuine radical movements have indeed caused positive societal change, but the toxic ones have caused millions of deaths.

In this contribution, we demonstrated that issue position polarization is not the most important explanation of radicalization. Adherents of radical ideas are not so much "left" or "right" in terms of their ideologically attitudes; indeed, they are not that distinct from moderate left- and right-wing voters in this respect. Rather they are politically cynical (along with being concerned with the negative effects of globalization and Wild West capitalism, or with immigration and the increasing presence of ethnic minorities). They are distrustful and driven by anger, and their information processing is heavily focused on consistency and closure. They distance themselves from traditional politics, and if the opportunity arises to reverse the establishment, they become politically effective.

Issue position polarization instead seems to play a role among moderate voters. The left-right cleavage is indeed highly predictive of differences in the electorate of the traditional party families. In the moderate group, the ideological left-right attitudes are "central" and the antimigration and antiglobalization attitudes seem to be surface manifestations that go along with the left-right dimension.

Hence, for (traditional) politics to become more effective, depolarization is needed for the moderate voter, and resocialization into the political system is needed for the radical voter. This resocialization is only possible when traditional parties succeed in regaining trust. Such trust repair will require them to take responsibility for government actions that have made a large portion of the population increasingly cynical, and which have become important concerns of radical voters.

\section{ACKNOWLEDGMENTS}

Correspondence concerning this article should be addressed to Alain Van Hiel, Department of Developmental, Personality and Social Psychology, Ghent University, H. Dunantlaan 2, 9000 Gent, Belgium. E-mail: Alain.VanHiel@UGent.be. An earlier version of some portions of this paper has been published in Van Hiel et al. (2021).

\section{REFERENCES}

Abou-Chadi, T. (2016). Niche party success and mainstream party policy shifts-How green and radical right parties differ in their impact. British Journal of Political Science, 46, 417-436.

Abramowitz, A., \& Saunders, K. L. (2008). Is polarization a myth? Journal of Politics, 7, 542-555. 
Abrams, D. A., Wetherell, M., Cochrane, S., Hogg, M. A., \& Turner, J. C. (1990). Knowing what to think by knowing who you are: Self-categorization and the nature of norm formation, conformity, and group polarization. British Journal of Social Psychology, 29, 97-119.

Adorno, T. W., Frenkel-Brunswik, E., Levinson, D. J., \& Sanford, R. N. (1950). The authoritarian personality. Harper.

Agger, R. E., Goldstein, M. N., \& Pearl, S. A. (1961). Political cynicism: Measurement and meaning. The Journal of Politics, 23, 477-506

Akkerman, A., Mudde, C., \& Zaslove, A. (2014). How populist are the people? Measuring populist attitudes in voters. Comparative Political Studies, 47, 1324-1353.

Allport, G. (1954). The nature of prejudice. Addison-Wesley.

Altemeyer, B. (1981). Right-wing authoritarianism. University of Manitoba Press.

Ashton, M. C., \& Lee, K. (2007). Empirical, theoretical, and practical advantages of the HEXACO model of personality structure. Personality and Social Psychology Review, 11, 150-166.

Bakir, V., \& McStay, A. (2018). Fake news and the economy of emotions: Problems, causes, solutions. Digital Journalism, 6, 154-175.

Bakshy, E., Messing, S., \& Adamic, L. A. (2015). Exposure to ideologically diverse news and opinion on Facebook. Science, 348(6239), 1130-1132.

Bartels, L. M. (2018). Partisanship in the Trump era. Journal of Politics, 80, 1483-1494.

Bartels, L. M. (2020). Ethnic antagonism erodes Republicans' commitment to democracy. Proceedings of the National Academy of Sciences of the United States of America, 117(37), 22752-22759.

Bass, B. M., \& Steidlmeier, P. (1999). Ethics, character, and the authentic transformational leadership behavior. Leadership Quarterly, 10, 181-217.

Billiet, J., \& Witte, H. (1995). Attitudinal dispositions to vote for a "new" extreme right-wing party: The case of "Vlaams Blok." European Journal of Political Research, 27(2), 181-202.

Brauer, M., Judd, C. M., \& Gliner, M. D. (1995). The effects of repeated expressions on attitude polarization during group discussions. Journal of Personality and Social Psychology, 68, 1014-1029.

Brown, R. (1965). Social psychology. Free Press.

Canovan, M. (1999). Trust the people! Populism and the two faces of democracy. Political Studies, 47, 2-16.

Carvalho, J. (2017). Mainstream party strategies towards extreme right parties: The French 2007 and 2012 presidential elections. Government and Opposition, 54, 365-386.

Chanley, V. A., Rudolph, T. J., \& Rahn, W. M. (2000). The origins and consequences of public trust in government: A time series analysis. Public Opinion Quarterly, 64(3), 239-256.

Citrin, J., \& Stoker, L. (2018). Political trust in a cynical age. Annual Review of Political Science, 21, 49-70.

Costa, P. T., \& McCrae, R. R. (1992). NEO PI-R, professional manual: Revised NEO Personality Inventory (NEO PI-R) and NEO Five-Factor Inventory (NEO-FFI). Psychological Assessment Resources Inc.

Da Silva, D. (2009). Towards a pedagogy of trust. Departmental Bulletin Paper.

De Ceulaer, J. (2020). Hoera! De democratie is niet perfect [Hoera! Democracy is not perfect]. Lannoo.

De Cremer, D., \& Van Hiel, A. (2010). Becoming angry when another is treated fairly: On understanding when own and other's fair treatment influences negative reactions. British Journal of Management, 21, 280-298.

De Cremer, D., \& Tyler, T. R. (2005). Managing group behavior: The interplay between procedural justice, sense of self, and cooperation. Advances in Experimental Social Psychology, 37, 151-218.

De Vreese, C. H. (2005). The spiral of cynicism reconsidered. European Journal of Communication, 20, $283-301$.

Dillet, B. (2017). What is poststructuralism? Political Studies Review, 15, 516-527.

Duckitt, J. (2001). A dual-process cognitive-motivational theory of ideology and prejudice. In M. P. Zanna (Ed.), Advances in experimental social psychology (Vol. 33, pp. 41-113). Academic Press.

Duckitt, J., Wagner, C., du Plessis, I., \& Birum, I. (2002). The psychological bases of ideology and prejudice: Testing a dual process model. Journal of Personality and Social Psychology, 83, 75-93.

Edelman Trust Barometer. (2021). Retrieved June 10, 2021, from https://www.edelman.com/trust/2021-trust-barometer

Eisinger, P. (2000). The politics of bread and circuses: Building the city for the visitor class. Urban Affairs Review, 35(3), 316-333.

Eysenck, H. J. (1954). The psychology of politics. Routledge \& Kegan Paul.

Fagerholm, A. (2018). The radical right and the radical left in contemporary Europe: two min-max definitions. Journal of Contemporary European Studies, 26, 411-424.

Fasel, N., Green, E. G., \& Sarrasin, O. (2013). Facing cultural diversity. European Psychologist, 18(4), 253-262.

Folger, R., \& Cropanzano, R. (1998). Organizational justice and human resource management. Sage. 
Frimer, J. A., Brandt, M. J., Melton, Z., \& Motyl, M. (2019). Extremists on the left and right use angry, negative language. Personality and Social Psychology Bulletin, 45, 1216-1231.

Gamson, W. (1975). The strategy of social protest. Dorsey.

Grant, R. W. (2008). Hypocrisy and integrity: Machiavelli, Rousseau, and the ethics of politics. University of Chicago Press.

Grover, P., Kar, A. K., Dwivedi, Y. K., \& Janssen, M. (2018). Polarization and acculturation in US Election 2016 outcomes-Can twitter analytics predict changes in voting preferences? Technical Forecasting and Social Change, $145,438-460$.

Hales, A. W., \& Williams, K. D. (2018). Marginalized individuals and extremism: The role of ostracism in openness to extreme groups. Journal of Social Issues, 74, 75-92.

Hameleers, M. (2020). Populist disinformation: Exploring intersections between online populism and disinformation in the US and the Netherlands. Politics and Governance, 8, 146-157.

Hardin, R. (2006). Trust. Polity Press.

Hartley, L. K., \& Pedersen, A. (2015). Asylum seekers and resettled refugees in Australia: Predicting social policy attitude from prejudice versus emotion. Journal of Social and Political Psychology, 3, 142-160.

Harton, H. C., \& Latané, B. (1997). Information- and thought-induced polarization: The mediating role of involvement in making attitudes extreme. Journal of Social Behavior and Personality, 12, 271-299.

Hasell, A., \& Weeks, B. E. (2016). Partisan provocation: The role of partisan news use and emotional responses in political information sharing in social media. Human Communication Research, 42, 641-661.

Haselmayer, M., \& Jenny, M. (2018). Friendly fire? Negative campaigning among coalition partners. Research and Politics, $5(3), 1-9$.

Hegel, G. W. F. (1970/1807). Phanomenologie des Geistes. Suhrkamp.

Hetherington, M. J. (1998). The political relevance of political trust. American Political Science Review, 92(4), 791-808.

Hobolt, S., \& Tilley, J. (2016). Fleeing the centre: The rise of challenger parties in the aftermath of the Euro crisis. West European Politics, 39, 971-991.

Huddy, L., Bankert, A., \& Davies, C. (2018). Expressive versus instrumental partisanship in multiparty European systems. Political Psychology, 39, 173-199.

Inglehart, R. F., \& Norris, P. (2016). Trump, Brexit, and the rise of populism: Economic have-nots and cultural backlash. HKS Working Paper No. RWP16-026. Retrieved March 16, 2020, from https://papers.ssrn.com/sol3/papers.cfm?abstr act_id=2818659

IPSOS. (2019). Retrieved November 6, 2019, from https://www.ipsos.com/sites/default/files/ct/news/documents/2019-09/ global-trust-in-professions-trust-worthiness-index-2019.pdf

Isenberg, D. J. (1986). Group polarization: A critical review and meta-analysis. Journal of Personality and Social Psychology, $50,1141-1151$.

Israel, J. (2014). Revolutionary ideas: An intellectual history of the French revolution. Princeton University Press.

Ivaldi, G. (2019). Populism in France. In D. Stockemer (Ed.), Populism around the world (pp. 27-48). Springer.

Iyengar, S., \& Westwood, S. J. (2015). Fear and loathing across party lines: New evidence on group polarization. American Journal of Political Science, 59, 690-707.

Jackson, J., Bradford, B., Hough, M., Myhill, A., Quinton, P., \& Tyler, T. R. (2012). Why do people comply with the law? Legitimacy and the influence of legal institutions. British Journal of Criminology, 52, 1051-1071.

Jost, J. (2019). Anger and authoritarianism mediate the effects of fear on support for the far right—What Vasilopoulos et al. (2019) really found. Political Psychology, 40, 705-711.

Judge, T. A., \& Zapata, C. P. (2015). The person-situation debate revisited: Effect of situation strength and trait activation on the validity of the Big Five personality traits in predicting job performance. Academy of Management Journal, 58, 1149-1179.

Karreth, J., Singh, S. P., \& Stojek, S. M. (2015). Explaining attitudes toward immigration: The role of regional context and individual predispositions. West European Politics, 38, 1174-1202.

Kollock, P. (1998). Social dilemmas: The anatomy of cooperation. Annual Review of Sociology, 24, 183-214.

Komorita, S. S., \& Parks, C. D. (1995). Interpersonal relations: Mixed-motive interaction. Annual Review of Psychology, 46, 183-207.

Lammers, J., Koch, A., Conway, P., \& Brandt, M. J. (2017). The political domain appears simpler to the politically extreme than to political moderates. Social Psychological and Personality Science, 8, 612-622.

Latané, B., \& Nowak, A. (1994). Attitudes as catastrophes: From dimensions to categories with increasing involvement. In R. Vallacher \& A. Nowak (Eds.), Dynamical systems in social psychology (pp. 219-249). Academic Press. 
Lemery, K. S., Essex, M. J., \& Smider, N. A. (2002). Revealing the relation between temperament and behavior problem symptoms by eliminating measurement confounding: Expert ratings and factor analyses. Child Development, 73 , 867-882.

Lengua, L. J., West, S. G., \& Sandler, I. N. (1998). Temperament as a predictor of symptomatology in children: Addressing contamination of measures. Child Development, 69, 164-181.

Liu, J. H., \& Latané, B. (1998). The catastrophic link between the importance and extremity of political attitudes. Political Behavior, 20, 105-126.

Machiavelli, N. (1532). The prince. Penguin.

Mason, L. (2015). "I disrespectfully agree": The differential effects of partisan sorting on social and issue polarization. American Journal of Political Science, 59, 128-145.

McDermott, R. (2019). Psychological underpinnings of post-truth in political beliefs. Political Science and Politics, 52, 218-222.

Mikula, G., Scherer, K. R., \& Athenstaedt, U. (1998). The role of injustice in the elicitation of differential emotional reactions. Personality and Social Psychology Bulletin, 24, 769-783.

Morris, D. S., Morris, J. S., \& Francia, P. L. (2020). A fake news inoculation? Fact checkers, partisan identification, and the power of misinformation. Politics, Groups, and Identities, 8, 986-1005.

Mosca, L., \& Tronconi, F. (2019). Beyond left and right: The eclectic populism of the Five Star Movement. West European Politics, 42, 1258-1283.

Moscovici, S. (1976). Social influence and social change. Academic Press.

Moscovici, S., \& Zavalloni, M. (1969). The group as a polarizer of attitudes. Journal of Personality and Social Psychology, $12,125-135$.

Mouffe, C. (2005). On the political. Verso.

Mudde, C. (2004). The populist zeitgeist. Government and Opposition, 39, 541-563.

Mudde, C. (2007). Populist radical right parties in Europe. Cambridge University Press.

Mudde, C., \& Rovira Kaltwasser, C. (2018). Studying populism in comparative perspective: Reflections on the contemporary and future research agenda. Comparative Political Studies, 51, 1667-1693.

Muller, J. W. (2016). What is populism?. University of Pennsylvania Press.

Myers, D. G. (1982). Polarizing effects of social interaction. In H. Brandstätter, J. H. Davis, \& G. Stocker-Kreichgauer (Eds.), Group decision making (pp. 125-161). Academic Press.

Myers, D. G., \& Lamm, H. (1976). The group polarization phenomenon. Psychological Bulletin, 83, 602-627.

Neustadt, R. E. (1990). Presidential power and the modern presidents: The politics of leadership from Roosevelt to Reagan. Free Press.

Nyhan, B., \& Reifler, J. (2010). When corrections fail: The persistence of political misperceptions. Political Behavior, 32(2), 303-330.

Oliver, J. E., \& Rahn, W. M. (2018). Rise of the "Trumpenvolk": Populism in the 2016 election. The Annals of the American Academy of Political and Social Science, 667, 189-206.

Onraet, E., Dhont, K., \& Van Hiel, A. (2014). The relationships between internal and external threats and right-wing attitudes: A three-wave longitudinal study. Personality and Social Psychology Bulletin, 40, 712-725.

Onraet, E., Van Hiel, A., Dhont, K., \& Pattyn, S. (2013). Internal and external threat in relationship with right-wing attitudes. Journal of Personality, 83, 233-248.

Patterson, T. E. (2002). The vanishing voter: Public involvement in an age of uncertainty. Alfred Knopf.

Pattyn, S., Van Hiel, A., Dhont, K., \& Onraet, E. (2012). Stripping the political cynic: A psychological exploration of the concept of political cynicism. European Journal of Personality, 26, 566-579.

Perottino, M., \& Guasti, P. (2020). Technocratic populism a la Francaise? The roots and mechanisms of Emmanuel Macron's success. Politics and Governance, 8, 545-555.

Pettigrew, T. F., \& Meertens, R. W. (1995). Subtle and blatant prejudice in Western Europe. European Journal of Social Psychology, 25, 57-75.

Petty, R. E., Briñol, P., Tormala, Z. L., \& Wegener, D. T. (2007). The role of metacognition in social judgment. In A. W. Kruglanski \& E. Higgins (Eds.), Social psychology: Handbook of basic principles (2nd ed., pp. 254-284). Guilford Press.

Pew Research Center. (2019a). Public trust in government: 1958-2019. Retrieved November 6, 2019, from https://www.peopl e-press.org/2019/04/11/public-trust-in-government-1958-2019/

Pew Research Center. (2019b). Findings about Americans' declining trust in government and each other. Retrieved November 6, 2019 from https://www.pewresearch.org/fact-tank/2019/07/22/key-findings-about-americans-declining-trust-in-gover nment-and-each-other/ 
Popper, K. R. (1945). The open society and its enemies. Routledge.

Porter, M. E. (2008). On competition. Harvard Business Press.

Pratto, F., Sidanius, J., Stallworth, L., \& Malle, B. (1994). Social dominance orientation: A personality variable predicting social and political attitudes. Journal of Personality and Social Psychology, 67, 741-763.

Pruit, D. G., \& Kimmel, M. J. (1977). Twenty years of experimental gaming—Critique, synthesis, and suggestions for future. Annual Review of Psychology, 28, 363-392.

Rico, G., Guinjoan, M., \& Anduiza, E. (2017). The emotional underpinnings of populism: How anger and fear affect populist attitudes. Swiss Political Science Review, 23, 444-461.

Rico, G., Guinjoan, M., \& Anduiza, E. (2020). Empowered and enraged: Political efficacy, anger and support for populism in Europe. European Journal of Political Research, 59, 797-816.

Roccato, M., Corbetta, P., Cavazza, N., \& Colloca, P. (2019). Assessment of citizens' populist orientations: Development and validation of the POPulist ORientation (POPOR) Scale. Social Science Quarterly, 100, 2148-2167.

Rokeach, M. (1960). The open and closed mind. Basic Books.

Rousseau, D., Sitkin, S., Burt, R., \& Camerer, C. (1998). Not so different after all: A cross-discipline view of trust. Academy of Management Review, 23, 393-404.

Rousseau, J. J. (1762). The social contract (Vol. 1). JM Dent \& Sons.

Ryan, T. J. (2012). What makes us click? Demonstrating incentives for angry discourse with digital-age field experiments. Journal of Politics, 74, 1138-1152.

Sanders, G. S., \& Baron, R. S. (1977). Is social comparison irrelevant for producing choice shifts? Journal of Experimental Social Psychology, 13, 303-314.

Scher, S. J., \& Darley, J. M. (1997). How effective are the things people say to apologize? Effects of the realization of the Apology Speech Act. Journal of Psycholinguistic Research, 26, 127-140.

Schmitt, M., Gollwitzer, M., Forster, N., \& Montada, L. (2004). Effects of objective and subject account components on forgiving. Journal of Social Psychology, 144, 465-485.

Sibley, C. G., \& Duckitt, J. (2008). Personality and prejudice: A meta-analysis and theoretical review. Personality and Social Psychology Review, 12, 248-279.

Sibley, C. G., Duckitt, J., Bergh, R., Osborne, D., Perry, R., Asbrock, F., Barlow, F. K., Robertson, A., Armstrong, G., \& Wilson, M. S. (2013). A dual process model of attitudes towards immigration: Person $\times$ residential area effects in a national sample. Political Psychology, 34, 553-572.

Sidanius, J. (1985). Cognitive functioning and sociopolitical ideology revisited. Political Psychology, 6, 637-661.

Simas, E. N., Clifford, S., \& Kirkland, J. H. (2020). How empathic concern fuels political polarization. American Political Science Review, 114, 258-269.

Simons, H. W., \& Mechling, E. W. (1981). The rhetoric of political movements. In D. D. Nimmo \& K. R. Sanders (Eds.), Handbook of political communication (pp. 417-444). Sage.

Stavrakakis, Y., \& Katsambekis, G. (2019). The populism/anti-populism frontier and its mediation in crisis-ridden Greece: From discursive divide to emerging cleavage. European Political Science, 18, 37-52.

Steinel, W., van Beest, I., \& van Dijk, E. (2014). Too good to be true: Suspicion-based rejections of high offers. Group Processes \& Intergroup Relations, 17, 682-698.

Suhay, E., \& Erisen, C. (2018). The role of anger in the biased assimilation of political information. Political Psychology, 39, 793-810.

Tett, R. P., \& Burnett, D. D. (2003). A personality trait-based interactionist model of job performance. Journal of Applied Psychology, 88, 500-517.

Toner, K., Leary, M. R., Asher, M. W., \& Jongman-Sereno, K. P. (2013). Feeling superior is a bipartisan issue: Extremity (not direction) of political views predicts perceived belief superiority. Psychological Science, 24, 2454-2462.

Tyler, T. R. (1990). Why people obey the law. Yale University Press.

Valentino, N. A., Brader, T., Groenendyk, E. W., Gregorowicz, K., \& Hutchings, V. L. (2011). Election night's alright for fighting: The role of emotions in political participation. Journal of Politics, 73, 156-170.

Van Assche, J., Dhont, K., Van Hiel, A., \& Roets, A. (2018). Ethnic diversity and support for populist parties: The "right" road through political cynicism and lack of trust. Social Psychology, 49(3), 182-189.

Van Assche, J., Van Hiel, A., Dhont, K., \& Roets, A. (2019). Broadening the individual differences lens on party support and voting behavior: Cynicism and prejudice as relevant attitudes referring to modern-day political alignments. European Journal of Social Psychology, 49, 190-199.

van den Bos, K. (2020). Unfairness and radicalization. Annual Review of Psychology, 71, 563-588.

Van Hauwaert, S. M., Schimpf, C. H., \& Azevedo, F. (2020). The measurement of populist attitudes: Testing cross-national scales using item response theory. Politics, 40, 3-21. 
Van Hauwaert, S. M., \& Van Kessel, S. (2018). Beyond protest and discontent: A cross-national analysis of the effect of populist attitudes and issue positions on populist party support. European Journal of Political Research, 57, 68-92.

Van Hiel, A. (2012). A psycho-political profile of moderates and left-wing and right-wing extremists. European Journal of Political Research, 51, 166-203.

Van Hiel, A., \& Mervielde, I. (2002). Explaining conservative beliefs and political preferences: A comparison of social dominance orientation and authoritarianism. Journal of Applied Social Psychology, 32(5), 965-976.

Van Hiel, A., \& Mervielde, I. (2003). The measurement of cognitive complexity and its relationship with political extremism. Political Psychology, 24(4), 781-801.

Van Hiel, A., \& Mervielde, I. (2005). Authoritarianism and social dominance orientation: Relationships with various forms of racism. Journal of Applied Social Psychology, 35, 2323-2344.

Van Hiel, A., Van Assche, J., \& Haesevoets, T. (2021). The political mindset of supporters of radical and populist Parties. In J.-W. Van Prooijen (Ed.), Political polarization (pp. 38-52). Routledge.

van Prooijen, J.-W., \& Krouwel, A. P. M. (2017). Extreme political beliefs predict dogmatic intolerance. Social Psychological and Personality Science, 8, 292-300.

van Prooijen, J.-W., Krouwel, A. P., Boiten, M., \& Eendebak, L. (2015). Fear among the extremes: How political ideology predicts negative emotions and outgroup derogation. Personality and Social Psychology Bulletin, 41, 485-497.

Van Zomeren, M. (2016). Building a tower of Babel? Integrating core motivations and features of social structure into the political psychology of action. Political Psychology, 37, 87-114.

Van Zomeren, M., Susilani, N., \& Berend, S. (2016). Explaining a rare null relationship between group identification and social protest through a relational form of coping. Journal of Social and Political Psychology, 4, 381-402.

Vasilopoulos, P., Marcus, G. E., \& Foucault, M. (2018). Emotional responses to the Charlie Hebdo Attacks: Addressing the authoritarianism puzzle. Political Psychology, 39, 557-575.

Vasilopoulos, P., Marcus, G. E., Valentino, N. A., \& Foucault, M. (2019a). Fear, anger, and voting for the far right: Evidence from the November 13, 2015 Paris terror attacks. Political Psychology, 40, 679-704.

Vasilopoulos, P., Marcus, G. E., Valentino, N. A., \& Foucault, M. (2019b). Applying the theory of affective intelligence to support for authoritarian policies and parties. Political Psychology, 40(S1), 109-139.

Verkuyten, M. (2004). Emotional reactions to and support for immigrant policies: Attributed responsibilities to categories of asylum seekers. Social Justice Research, 17, 293-314.

Vinokur, A., \& Burnstein, E. (1974). Effects of partially shared persuasive arguments on group-induced shifts: A groupproblem solving approach. Journal of Personality and Social Psychology, 29, 305-315.

Wagner, M. (2014). Fear and anger in Great Britain: Blame assignment and emotional reactions to the financial crisis. Political Behavior, 36, 683-703.

Weber, C. (2013). Emotions, campaigns, and political participation. Political Research Quarterly, 66, 414-428.

Webster, S. W. (2018). Anger and declining trust in government in the American electorate. Political Behavior, 40, 933-964.

Weeks, B. E. (2015). Emotions, partisanship, and misperceptions: How anger and anxiety moderate the effect of partisan bias on susceptibility to political misinformation. Journal of Communication, 65, 699-719.

Westfall, J., Van Boven, L., Chambers, J., \& Judd, C. M. (2015). Perceiving political polarization in America: Party identity strength and attitude extremity exacerbate the perceived partisan divide. Perspectives on Psychological Science, 10(2), $145-158$.

Weyland, K. (2020). Populism's threat to democracy: Comparative lessons for the United States. Perspectives in Politics, 18, 389-406.

Whiteley, P., Larsen, E., Goodwin, M., \& Clarke, H. (2021). Party activism in the populist radical right: The case of the UK Independence Party. Party Politics, 27, 644-655.

Wollebaek, D., Karlsen, R., Steen-Johnsen, K., \& Enjolras, B. (2019). Anger, fear, and echo chambers: The emotional basis for online behavior. Social Media and Society, 5 (2), Article 2056305119829859.

Wuttke, A., Schimpf, C., \& Schoen, H. (2020). When the whole is greater than the sum of its parts: On the conceptualization and measurement of populist attitudes and other multidimensional constructs. American Political Science Review, 114, 356-374.

Zmigrod, L., Rentfrow, P. J., \& Robbins, T. W. (2020). The partisan mind: Is extreme political partisanship related to cognitive inflexibility? Journal of Experimental Psychology: General, 149, 407-418.

Zweig, S. (1943). The world of yesterday: An autobiography. The Viking Press. 